\title{
Climate projection of Lake Superior under a future warming scenario
}

\author{
Katsumi MATSUMOTO, ${ }^{*}$ Kathy S. TOKOS, Joseph RIPPKE \\ Department of Earth and Environmental Sciences, University of Minnesota, 116 Church Street SE, Minneapolis, MN 55455, USA
}

\begin{abstract}
In a future warming world, a fully dynamical model of Lake Superior projects that the lake will undergo significant physical and biological changes by the middle of the $21^{\text {st }}$ century with important implications for the surrounding region. Projections for the winter include drastically reduced ice and very weak water column stratification. In contrast, the summertime surface warming is projected to begin earlier, last longer, and be more enhanced. In concert, summertime biological production is projected to shift earlier and become larger. These changes have potentially important consequences for stakeholders with interests in shipping, coastal habitability, fishing, water quality, and recreation. Perhaps more fundamentally, the projected changes imply that Lake Superior may change into a different kind of lake with a dramatically weakened dimictic behavior.
\end{abstract}

\section{INTRODUCTION}

The most recent Intergovernmental Panel on Climate Change assessment report (IPCC, 2013) confirms earlier IPCC reports that global warming is both detected against the background of natural climate variability and that the warming is largely attributable to human activities. This warming, which has been observed for over a century, has become markedly stronger in the recent decades. In response, animals and plants, from mollusks to mammals and from grasses to trees, have shown temperature-related shifts worldwide (Root et al., 2003). Spring phenologies, such as flowering, egg laying, and migration, are occurring earlier in the year, and such changes are greatest in the higher latitudes where warming has been largest.

In the United States, the Third National Climate Assessment (Melillo et al., 2014) notes that climate change

Corresponding author: katsumi@umn.edu

Key words: Climate projection; Lake Superior; numerical model; Great Lake.

Acknowledgments: This work was supported by NASA Physical Oceanography grant NNX13AM85G to KM. Numerical modeling and analysis were carried out using resources at the University of Minnesota Supercomputing Institute (MSI).

Edited by: Alberto Doretto, University of Piemonte Orientale "Amedeo Avogadro", Alessandria, Italy.

Received: 12 March 2019.

Accepted: 4 July 2019.

This work is licensed under a Creative Commons Attribution NonCommercial 4.0 License (CC BY-NC 4.0).

${ }^{\circ}$ Copyright: the Author(s), 2019

Licensee PAGEPress, Italy

J. Limnol., 2019; 78(3): 296-309

DOI: 10.4081/jlimnol.2019.1902 impacts are felt across the country in widely varying sectors today and that the trends will continue into the future. For example, in the Midwest, extreme rainfall events and flooding have increased over the last century; in the future, they are expected to cause declining water quality and adversely impact transportation, agriculture, and human health. Increasing surface air temperature (SAT) is expected to have similarly negative impacts in the Midwest. For the Laurentian Great Lakes, the National Climate Assessment speculates that reduced ice, more intense storms, increased precipitation, and continued warming will to lead to enhanced shore erosion, more flooding, loss of fish habitat, shifts in the range and distribution of certain fish species, and increase in harmful algal blooms as well as invasive species (Pryor et al., 2014).

Lake Superior is a large aquatic system that is relatively undisturbed by humans. The watershed of Lake Superior is mostly forested, and the amount of water withdrawn for consumption is only a small fraction of the amount withdrawn from the other Laurentian Great Lakes (The Great Lakes Commission, Annual Report 2006, https:/www.glc.org/wp-content/uploads/2016/10/2006glc-annual-report.pdf). It is the world's largest lake by surface area with a mean depth of $147 \mathrm{~m}$ and maximum depth of $406 \mathrm{~m}$ (Fig.1). For its size, Superior has a relatively small watershed, located within the Canadian Shield, whose rocks are strongly resistant to weathering. Thus the allochthonous loading of dissolved constituents including nutrients is limited. As a result, the lake is oligotrophic and its organic carbon cycle is dominated by microbes (Cotner et al., 2004).

Despite its relatively undisturbed nature, Lake Superior is undergoing substantial warming. For example, a record of nearly 100 years of temperature data from the St. Marys River, which drains Lake Superior, indicates a clear, long term trend of lake warming (McCormick and Fahnenstiel, 1999; Austin and Colman, 2008). Over this period, summer stratification of the water column started progressively earlier and ended more or less about the same time of year, 
so that the summer stratified period became longer by nearly two weeks. Similarly, a 150 year record from a ferry operator in Bayfield, Wisconsin shows a consistent decrease in the length of the ice covered season at a rate of 3 days per decade from 1857 to 2007 (Howk, 2009). In four recent winters (1998-1999, 2012-2013, 2015-2016, and 2016-2017), the lack of ice has allowed the ferry to operate continuously through the winter (Madeline Island Ferry Line). In the open waters of Lake Superior, warming of lake water surface temperature (LWST) has accelerated in recent decades as recorded by NOAA buoys (Austin and Colman, 2007). At the same time, the spatially and temporally averaged lake wide ice cover over the winter season from 1979 to 2005 has decreased at a rate of $4.2 \%$ per decade (Assel, 2003, 2005).

Warming in Lake Superior has not been steady though. The warming of 1998, coincident with a prominent El Niño event, was particularly strong and received attention (Van Cleave et al., 2014; Piccolroaz et al., 2015; Zhong et al., 2016). The strength of the 1998 warming was such that much of the warming in Lake Superior over the period 1973-2010 could possibly be explained by a single, step change without a long term trend (Van Cleave et al., 2014).

The warming seen in Lake Superior fits the larger context of warming reported for the Laurentian Great Lakes in general (Mason et al., 2016; Zhong et al., 2016, 2018) and more geographically distributed lakes (Schmid et al., 2014; O'Reilly et al., 2015; Woolway and Merchant, 2018). In their global synthesis of in situ and remotely sensed data for 235 lakes, O'Reilly et al. (2015) show that summertime LWST increased globally by over $0.3^{\circ} \mathrm{C}$ per decade during the period $1985-2009$. While warming is almost universally observed, there is substantial interlake variation, which no single geographic or morphometric factor could explain. Instead the variation in warming is attributed to different combinations of climate and local characteristics so as to preclude regional consistency. Even within single (large) lakes, warming is often heterogeneous. For example, deeper parts of Laurentian Great Lakes warm at faster rates than shallower parts (Mason et al., 2016; Zhong et al., 2016). Such thermal response may be related to a greater persistence of temperature anomalies from previous times within a longer water column (Woolway and Merchant, 2018).

A number of attempts have been made to project the historical warming trends into the future. Different types of lake models have been employed to make such projections. The simpler models are statistical/hybrid models that vary in sophistication but utilize some empirical relations between LWST and environmental variables such as surface air temperature. Such models have been applied to Lake Superior (Trumpickas et al.,
2009), Lake Tahoe (Piccolroaz et al., 2018), and smaller lakes in Poland (Czernecki and Ptak, 2018), Canada (Shuter et al., 2013), and the Rocky Mountains (Roberts et al., 2017). More sophisticated 1D thermal dynamic models have been employed for future projections of smaller US lakes (Fang and Stefan, 2009; Butcher et al., 2015) and a German lake (Weinberger and Vetter, 2014).

In this study, we use a well-tested 3D model of Lake Superior to simulate its dynamics and biogeochemistry under a future warming scenario. We have previously described the model (White et al., 2012) and used it in investigations of chlorophyll distributions (White and Matsumoto, 2012), interior ventilation (Matsumoto et al., 2015), and lateral exchange of onshore and offshore waters (McKinney et al., 2018). There are other mechanistic models applied to Lake Superior with varying degrees of sophistication from 1D models (Sugiyama et al., 2018; Zhong et al., 2018) to 3D models (Schwab and Bedford, 1999; Chen et al., 2001; Bennington et al., 2010; Xue et al., 2015; Ye et al., 2019). The regional modeling system of Xue et al. (2017) is unique in representing all five Laurentian Great Lakes together, each in 3D, and coupled to a regional climate model. To our knowledge, ours would be the first study to employ a realistically configured 3D model of a Great Lake to make a future projection.

Future climate projections focused on the US Great Lakes region have been reported previously (Hayhoe et al., 2010; Music et al., 2015). Hayhoe et al. (2010) downscaled future climate projections from a few global atmospheric-ocean general circulation models (AOGCMs) in order to clarify regional implications of global warming under different IPCC greenhouse gas emission scenarios: A1 (fossil-intensive, higher); A2 (middle); and B1 (lower) scenarios from an IPCC special report on emissions (Nakicenovic et al., 2000). They conclude that annual temperatures in the Great Lakes region are projected to increase by $2 \sim 3^{\circ} \mathrm{C}$ by mid-century relative to the late $20^{\text {th }}$ century. Music et al. (2015) analyzed regional climate model outputs from the North American Regional Climate Change Assessment Program (NARCCAP) (Mearns et al., 2013) to investigate the future water budget of the region. The same IPCC scenarios drive NARCCAP, which is described in more detail below as we too make use of its climate projections as drivers of our Lake Superior model. Music et al. (2015) conclude that the future water budget will fluctuate more over the seasons but with no change in the annual mean.

Lessons gained from available studies of Lake Superior (Piccolroaz et al., 2015; Zhong et al., 2016, 2018; Ye et al., 2019) would suggest that the regional warming projected by Hayhoe et al. (2010) will drive a continuation or even an acceleration of the warming trends already observed. They include, for example, 
milder winter LWST, reduced ice cover, and longer and stronger summer stratification, although the specifics of those trends in the future are unclear. It is entirely unclear what biological characteristics of Lake Superior may change in the future, and what their economic, environmental, and social repercussions might be.

This study would begin to fill those gaps in knowledge. Our objective is to present a spatially resolved, mid-century (2040-2069) climate projection of Lake Superior under a future warming scenario. Our projections include temperature and ice distributions, water column stratification, mixing, and primary production, all of which have important implications for human welfare, such as coastal water quality and habitability, fisheries, shipping, and recreation. It is important to point out that climate projections based on emission scenarios are not predictions, but rather represent plausible future conditions under a particular set of assumptions (IPCC A2 in this case). Such projections for the Great Lakes are potentially useful in anticipating future changes and initiating conversations about possible adaptation strategies.

\section{METHODS}

\section{Model description}

Our spatially explicit model of Lake Superior is based on the Regional Ocean Modeling System, a free-surface primitive equation ocean model (Shchepetkin and
McWilliams, 2005). The Lake Superior model has a realistic shoreline and bathymetry and a closed model domain (Fig. 1). It consists of 20 depth-following sigma layers, which vary in thickness from less than a meter at the surface to nearly 50 meters in the deepest areas of the lake, and an equal-area, rectangular horizontal grid scale of $5 \mathrm{~km}$. While earlier models of Lake Superior lacked an ice model (Schwab and Bedford, 1999; Chen et al., 2001; Bennington et al., 2010), our model includes a prognostic model of ice dynamics and thermodynamics. More recently developed models also have ice models (Xue et al., 2015; Ye et al., 2019). Ice is a critical component of Lake Superior's seasonal cycle (Titze and Austin, 2014) and thus important to have in a credible climate projection of the lake. Our model is unique in having an NPZD-type ecosystem model that predicts phytoplankton, chlorophyll, zooplankton, and phosphate among other state variables. In the ecosystem model, primary production is driven by phytoplankton growth, which depends on various ambient environmental conditions, source minus sink terms such as zooplankton grazing, mortality, and particle coagulation. Zooplankton biomass increases by grazing on phytoplankton and decreases by excretion and mortality. Plankton can coagulate to form detrital particles, which settle out of the water column. Chlorophyll within phytoplankton can vary so as to allow for photoadaptation (i.e., variable chlorophyll:C ratio arising from variable allocation of cellular resources into making different macromolecules). The ecosystem model is fully described in White and Matsumoto (2012). The

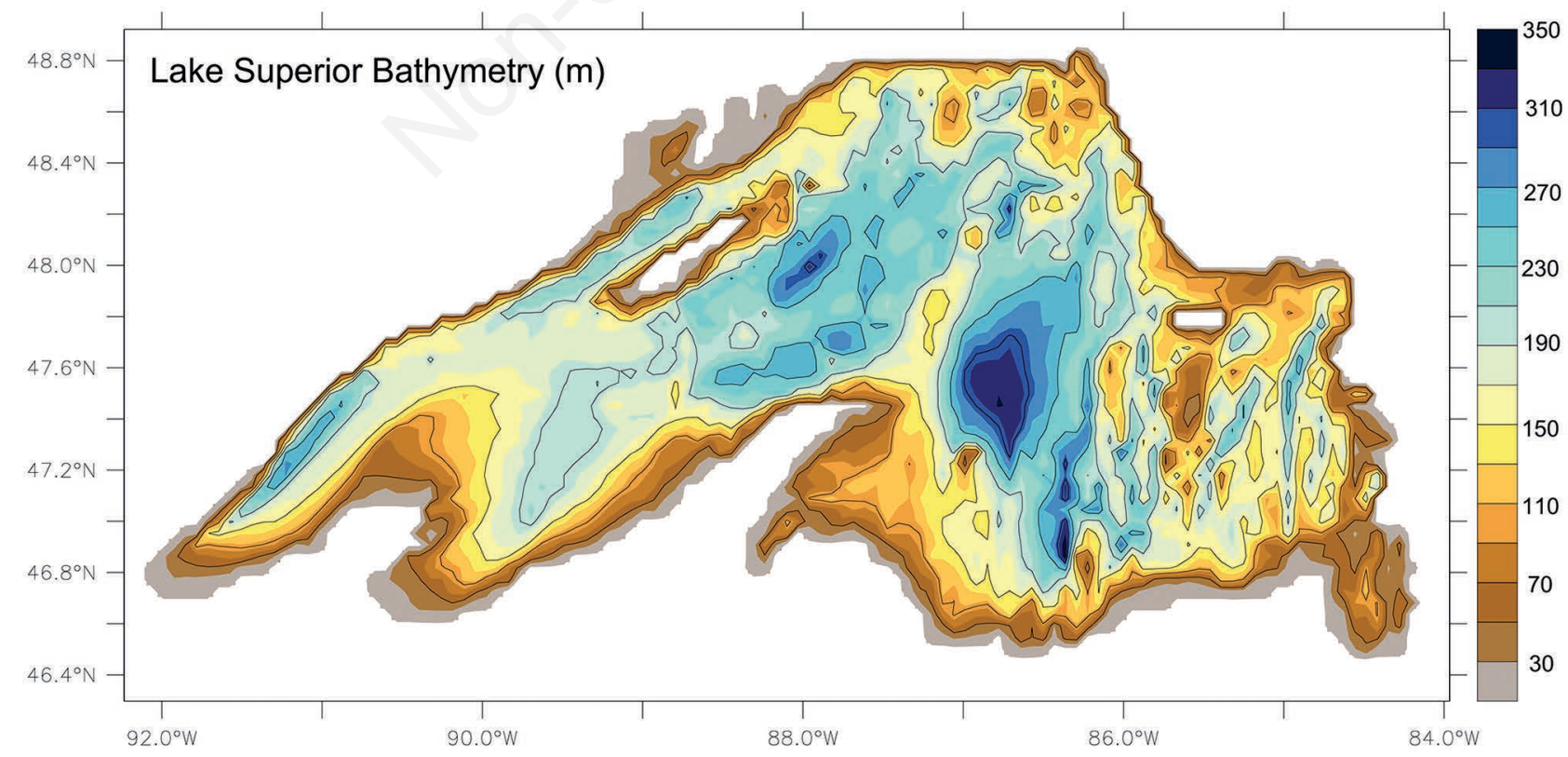

Fig. 1. Bathymetry of Lake Superior. 
overall model architecture, its physical and biogeochemical parameters, and choice of parameter values are described by White et al. (2012).

In previous studies, our Lake Superior model successfully captured several key features of the lake, including: general timing of its dimictic behavior, seasonal migration of the $4^{\circ} \mathrm{C}$ thermal front from the coast to offshore, initial formation of lake ice along the periphery of lake; general ice advection from west to east, and primary production and the associated deep chlorophyll maximum. Model-simulated fields and seasonal cycles of temperature, ice, and chlorophyll have been assessed extensively through comparisons against available data, such as the NOAA buoy temperature data, ice atlases, and EPA station chlorophyll measurements (White et al., 2012; Matsumoto et al., 2015; McKinney et al., 2018). Time series analysis also showed that our model simulates well the seasonal evolution, secular trends, and interannual variability of temperature and ice (White et al., 2012). For example, over the simulation period of 1985-2008, lakewide LWST increased $0.10 \pm 0.05^{\circ} \mathrm{C}^{-1}$, which compares favorably to the rate of $0.11 \pm 0.06^{\circ} \mathrm{C} \mathrm{y}^{-1}$ reported for 1979 to 2006 (Austin and Colman, 2007).

The model also compared well in terms of eddy locations. In an earlier work, we had identified eddies in Lake Superior on the basis of satellite-based Synthetic Aperture Radar and thermal imagery (McKinney et al., 2012). In a follow-up study using our Lake Superior model, we used an objective algorithm to detect eddies in our model simulations and found that the eddy locations in the model domain were consistent with where eddies were identified in Lake Superior using satellite imagery (McKinney et al., 2018).

Large scale biological features simulated by the model compared favorably to available data (White et al., 2012). For example, the lakewide annual primary production in the model for the 1985-2008 period is approximately 6.2 $\operatorname{Tg~C~} \mathrm{yr}^{-1}\left(\mathrm{Tg} \mathrm{C}=10^{12}\right.$ grams C), which compares well to data-based estimates (Cotner et al., 2004; Urban et al., 2005; Sterner, 2010). Also, White and Matsumoto (2012) showed that the model is able to reproduce the deep chlorophyll maximum (DCM), a ubiquitous feature in Lake Superior (Barbiero and Tuchman, 2004). Both primary production and DCM are strongly dependent on velocity fields for nutrient supply, and so their good datamodel comparisons add confidence that the model physics are reasonable.

These assessment exercises however show that the model tended to overestimate the summertime warming, the onset of springtime warm up, and, although to a lesser extent, the fall cool down. There are two reasons for the overestimate. First, the mixed layer depth in the model is too shallow, a problem noted in other models of the Great
Lakes (Beletsky and Schwab, 2001; Huang et al., 2010) and the Bering Sea (Hu and Wang, 2010) that have the same level 2.5 closure turbulence model (Mellor and Yamada, 1982). Hu and Wang (2010) argue that such models lack wind-wave mixing scheme to realize a sufficiently deep mixed layer. Second, in two of our previous studies (Matsumoto et al., 2015; McKinney et al., 2018), we have used the North American Regional Reanalysis (NARR) to force the model. NARR is known to cause a warm bias in Lake Superior modeling (Bennington et al., 2010).

\section{Forcing fields}

Our model of Lake Superior is not coupled to an atmospheric model and thus requires several atmospheric boundary conditions: surface radiative fluxes, wind, air temperature, pressure, humidity, and precipitation. For this study, we use the mid-century output of the Canadian Regional Climate Model (CRCM) (Caya and Laprise, 1999), nested within the Community Climate System Model (CCSM) (Collins et al., 2006). This was one of several regional model-global model combinations used in NARCCAP, which assessed the ability of 6 regional climate models (RCMs) to predict local climate impacts under global warming. As noted above, NARCCAP outputs were used in a recent water budget projections of the US Great Lakes region (Music et al., 2015). Under NARRCCAP, the RCMs were nested within global AOGCMs and driven by the radiative forcing of the IPCC A2 emission scenario (Nakicenovic et al., 2000). The A2 scenario is a 'business as usual' increase in atmospheric $\mathrm{CO}_{2}$ and reaches over $800 \mathrm{ppm}$ by the year 2100 . It is the intermediate scenario between the A1 and B1 scenarios. We note that newer scenarios have been developed as the global society, geopolitics, and technology evolved. Of the five scenarios developed as part of the latest Shared Socioeconomic Pathways (SSP), the A2 scenario resembles SSP3, the middle of the new scenarios (Riahi et al., 2017).

In NARCCAP, multiple RCM-AOGCM combinations were run for the historical period of 1970-2000 and under the mid-century conditions for years 2040-2070. Of the multiple combinations available, we chose for this study the CRCM-CCSM combination, which seems well suited to describing the Great Lakes region, and Lake Superior specifically. An initial NARCCAP comparison of the regional models showed some to be less adept at modeling LWST and ice formation in the Great Lakes region, whereas CRCM was able to closely match observations in the region including Lake Superior (http://www. narccap.ucar.edu/results/cru-results.html). Of the participating AOGCMs, CCSM has the highest spatial resolution.

For the historic period of 1990-1999, SAT forcing over 
Lake Superior from CRCM-CCSM is largely consistent with that from NARR and Great Lakes Coastal Forecasting System (GLCFS) (Schwab and Bedford, 1999). This includes summertime maximums and spring and fall transitions. The largest discrepancy is in a brief transition period in late winter, when the CRCM-CCSM air temperatures fall by up to $7^{\circ} \mathrm{C}$ below the GLCFS and NARR averages due to lead-lag of the transition period. When SAT from CRCM-CCSM is compared against the seasonal NOAA buoy data, the former warms more quickly toward the summer maximum than the latter.

During the 1990s, the CRCM-CCSM winds are generally comparable to the GLCFS reanalysis and the buoy data, although they tend to be lower in the winter, and higher in the summer and fall. This could result in earlier winter overturning in the model than actually occurs. Generally, the strongest winds occur in the fall and cover larger geographic areas than in the spring, and thus mix all regions of the lake more thoroughly and simultaneously.

Also during the 1990s, the CRCM-CCSM shortwave radiation and downwelling longwave radiation are weaker than NARR. As a result, LWST in our model shows lower peak summertime temperatures by up to $1.5^{\circ} \mathrm{C}$ compared to satellite-derived lake surface temperatures (NOAA CoastWatch/OceanWatch,

https://coastwatch.glerl.noaa.gov/ statistic/statistic.html, 2018). If the same bias were to persist in future projections of CRCM-CCSM, our projection of LWST would likely be biased low as well. Fig. 2 compares model-simulated LWST climatology for the 1990s against NOAA National Data Buoy Center open-lake buoys. The comparison shows that the simulated LWST displays a reasonable seasonal variability and mostly stays within the envelopes of buoy observations.

For the future period, the temperature and precipitation response of the CRCM-CCSM combination is positioned just about in the middle of the all the RCMAOGCM combinations in NARCCAP (Mearns et al., 2013). Therefore, we consider our future climate projection of Lake Superior to be near the middle of the range of possible warming outcomes.

Of the CRCM-CCSM fields used to force the Lake Superior model, only SAT showed significant changes between the 1990s and mid-century projections. Air temperature will thus be the main driver of climate change projection. When considered over the 80-year span between 1990 and 2070, air temperature in CRCMCCSM is projected to rise $0.04^{\circ} \mathrm{C}_{\text {year }}{ }^{-1}$, mostly due to an increase in summertime maximum temperatures. The frequency distributions of surface air temperatures for the 1990s and the mid-century decades show a clear shift towards higher temperatures with time (not shown). The shift in the mean SAT is $2 \sim 3^{\circ} \mathrm{C}$ between the 1990s and the mid-century. There is little change in the variance of the distributions.

\section{Numerical experiments and passive tracers}

For the historical period, the Lake Superior model was forced with the 1990-1999 CRCM-CCSM outputs as atmospheric boundary conditions. This was to establish a historical reference for the future projections. The first two years $(1990,1991)$ are used to spin up the model from a static state, and therefore years 1992-1999 are used for analysis. For the mid-century simulations, we use the CRCM-CCSM output for years 2038-2070 as boundary conditions. Again the first two years $(2038,2039)$ are spin up, leaving 2040-2070 for analysis.

We included an idealized, passive tracer for both historical and future runs. The tracer Age is used to quantify the time that interior waters have been isolated from the atmosphere. As previously described (Matsumoto et al., 2015), Age is initially set everywhere to zero and transported passively in the model by advection and diffusion. The tracer is continuously reset to zero throughout the simulations at the surface, but everywhere else, Age increments by time step $\Delta$ t. This means that as soon as a parcel of water leaves the surface and becomes isolated from the atmosphere, the clock begins to tick. Under steady state, Age in the model domain would eventually achieve equilibrium, when aging is balanced by the transport of younger, more ventilated waters. However, episodic mixing such as convective overturning can rapidly

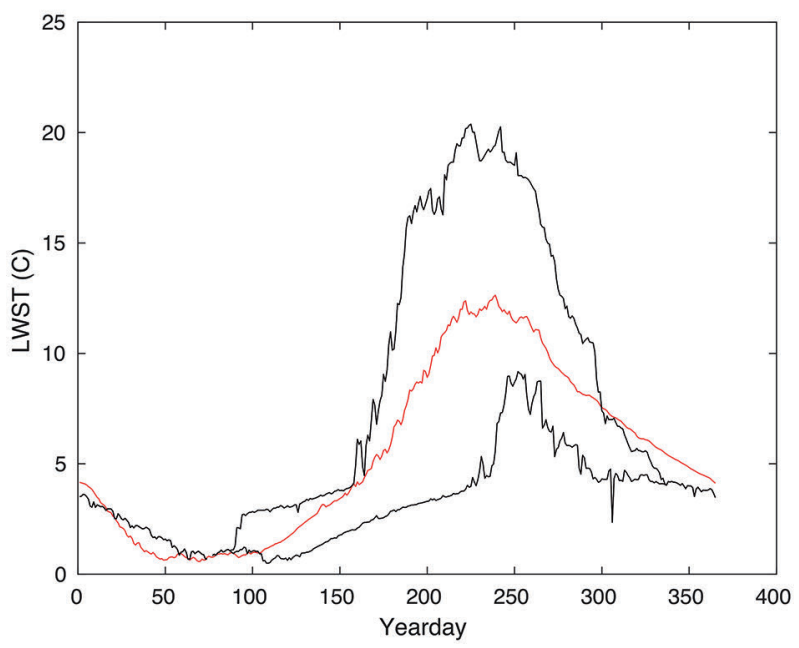

Fig. 2. LWST climatology for the 1990s. Red, model-simulated LWST; black, envelopes of 1990s surface temperature from NOAA buoys, which are typically taken out of water in the winter months. In 1991 the eastern buoy was not taken out; the figure's lower envelope over the winter months show the 1991 eastern buoy data. 
make Age in the interior younger and even approach zero. Age of a water parcel thus represents the weighted average time for the surface waters to reach the interior, so that a poorly ventilated interior grid box will have an older age. Waters near the surface will be younger in age. In our previous study (Matsumoto et al., 2015), Age clearly showed Lake Superior's dimictic behavior and indicated preferential vertical mixing over rough bottom topography. The deep water Age is reset (i.e., approached zero) during spring and fall overturning. However, the degree of this resetting depends on the extent of the overturning. In this study, Age will be used to understand how overturning and deep water isolation may change in the future.

\section{RESULTS}

\section{Projection of Lake Superior climate}

As expected, the model of Lake Superior, forced by the CRCM-CCSM climate conditions under the A2 emissions scenario, projects increasingly warmer conditions. This is clearly seen in the changes in LWST, the mixed layer depth (MLD), and ice between the mid- century decades and the 1990s (Figs. 3 and 4). Annual lakewide mean LWST increases by nearly $3^{\circ} \mathrm{C}$ from 5 $6^{\circ} \mathrm{C}$ in the 1990 s to almost $9^{\circ} \mathrm{C}$ in the late 2060s (Fig. 3a). This represents a balance between the large summertime LWST change and the very limited wintertime change. The winter LWST does not change much, because the temperature of freezing pegs the lower end of the temperature excursion. Spatially, LWST increases more in the eastern basin of Lake Superior where today LWST is low and water depth is greatest (Fig. 4 a,b), a pattern of warming observed today (Mason et al., 2016; Woolway and Merchant, 2018; Zhong et al., 2018).

MLD is defined as the depth $\mathrm{z}$ where $\mathrm{T}_{\mathrm{z}=0}-\mathrm{T}_{\mathrm{z}}<0.1^{\circ} \mathrm{C}$ and above $75 \mathrm{~m}$. Lakewide averaged MLD shows a clear trend of shoaling over the decades (Fig. 3b). During the 1990 s, MLD is approximately $28 \mathrm{~m}$ and shoals to $22 \mathrm{~m}$ by the late 2060s. MLD is generally shallow in waters where bathymetry is shallow (Fig. 4c). By mid-century, MLD shoals in most parts of Lake Superior but is pronounced in the deeper, midlake regions (Fig. 4d).

In the winter, the prominence of ice as a surface feature of Lake Superior becomes significantly diminished (Fig. 3c). During the decade of the 1990s, the lakewide ice

\section{a) Mean LWST}

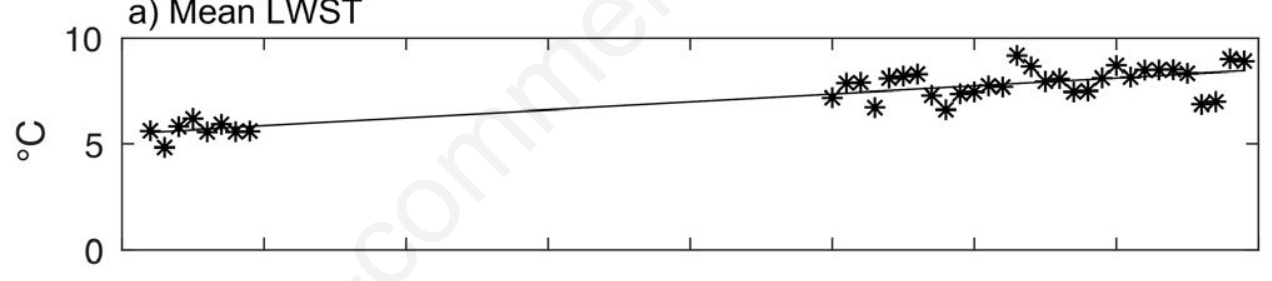

b) Mixed Layer Depth

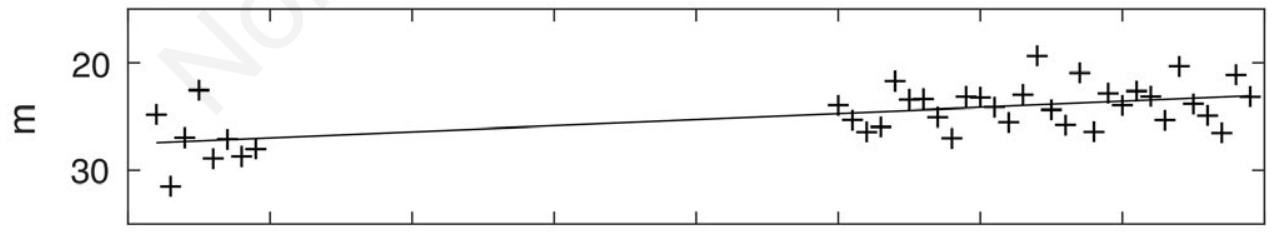

c) Ice Cover

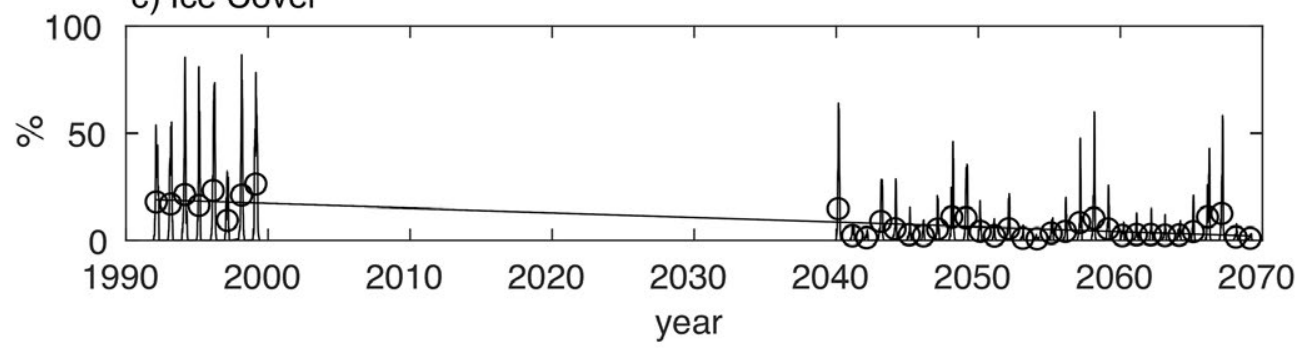

Fig. 3. Time series of modeled annual lakewide mean physical characteristics for the historical period 1992-1999 and a future projected scenario 2040-2069. a) Lake water surface temperature; b) mixed layer depth; c) percent ice cover (annual average in circles; and daily average in lines). Trend lines are least-squares linear fit to the annual averages and are statistically significant. 
cover averaged over the ice season, here defined as 1 December until 31 May, spans 10-30\% (Fig. 3c, open circles). The same quantity decreases significantly in the mid-century to mostly below $10 \%$. It is important keep in mind that in any given year, the daily ice coverage can vary between few percent and over $90 \%$ (Fig. 3c, line). The maximum daily ice cover in the model exceeded $70 \%$ in half of the years in the 1990s. In contrast, there is only one year in the 2040-2070 period when the daily maximum exceeds $70 \%$. The daily maximum ice coverage is less than $10 \%$ in 11 years out of the 30 -year period. Spatially, the greatest loss of winter ice is seen in relatively shallow coastal areas along the eastern sides of the basin (Fig. 4f). The eastern side is where ice accumulates in the model during the 1990s (Fig. 4e) as a result of westerly winds blowing ice in that direction, a phenomenon that is consistent with observations (Titze and Austin, 2016). The model projects hardly any ice in the open waters of Lake Superior in the mid-century.

One of the important consequences of the ongoing warming trend is that the summer stratified period becomes longer, primarily because the starting date of a) LWST $\left({ }^{\circ} \mathrm{C}\right)$

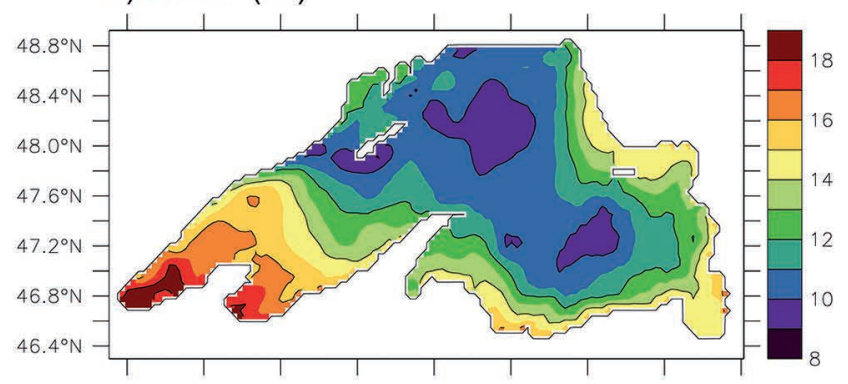

c) MLD (m)

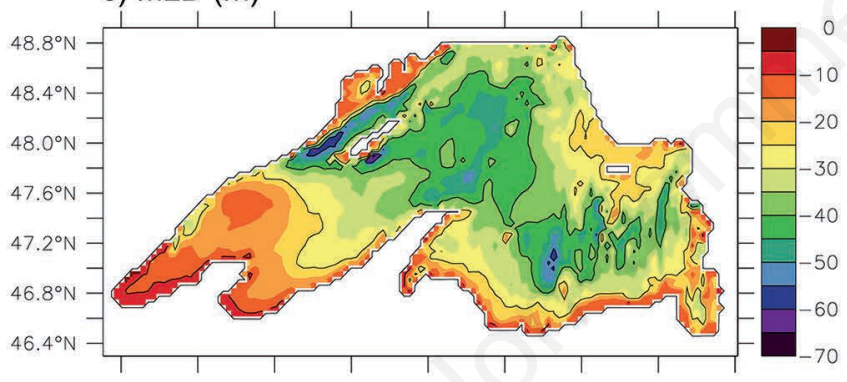

e) Ice Cover (\%)

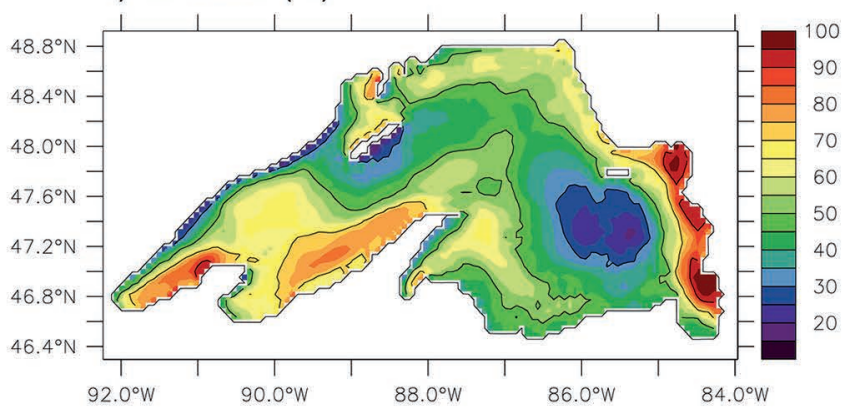

b) $\Delta$ LWST $\left({ }^{\circ} \mathrm{C}\right)$

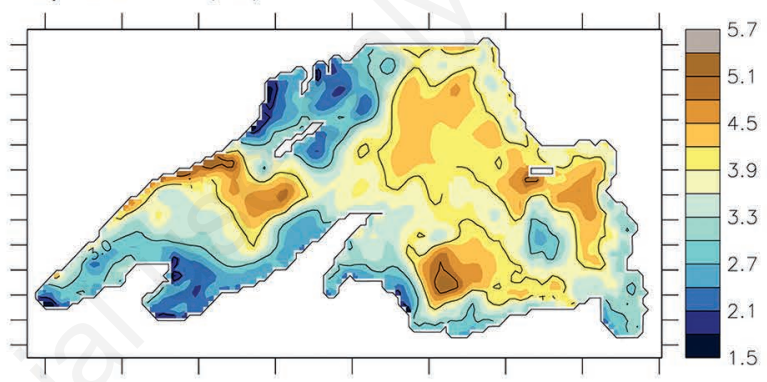

d) $\triangle M L D(m)$

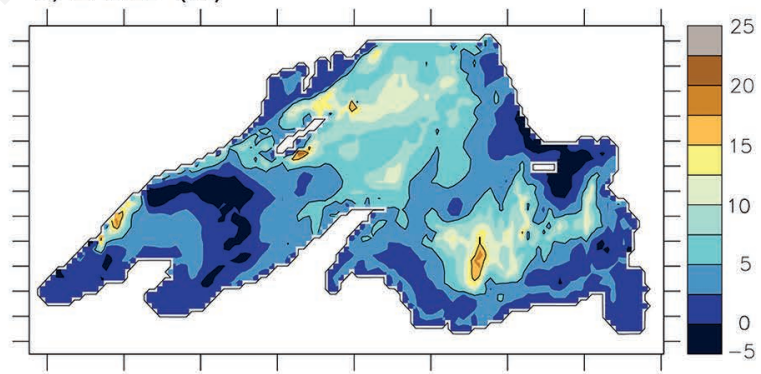

f) $\Delta$ Ice Cover (\%)

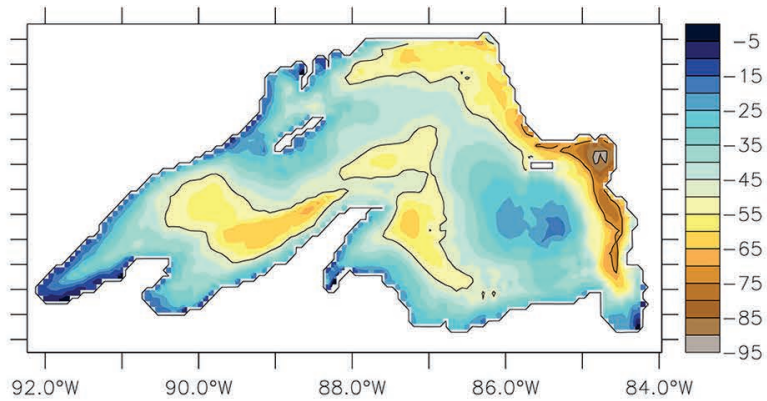

Fig. 4. Decadal climatologies of lake water surface temperature (LWST), mixed layer depth (MLD), and ice cover for the 1990s and their changes by 2060s (2060s-1990s). a) LWST climatology for 1990s; b) LWST change by 2060s; c) MLD climatology for 1990s; d) MLD change by 2060s; e) ice coverage for 1990s; f) ice cover change by 2060s. In panels (b) and (d), positive values indicate higher temperatures and shallower MLD, respectively. Negative values in (f) indicate greater ice reduction. LWST and ice cover are shown for the year day when their lakewide mean is maximum: LWST, August 12; ice cover, February 27. MLD is shown for the period when it exists as defined: June 28-October 25 for the 1990s and May 28-November 10 for the 2060s. 
stratification occurs progressively earlier in the year (Austin and Colman, 2008). In this study, the summer stratified period is defined as the period between spring/summer when lakewide mean LWST rises above $4^{\circ} \mathrm{C}$ and autumn/winter when it drops below $4^{\circ} \mathrm{C}$. The summer stratified becomes 60 days longer between 1990s and the mid-century.

During the transition period to the summer stratified period, the spring thermal bar or $4^{\circ} \mathrm{C}$ isotherm is present somewhere in the lake surface. Fig. 5 shows the decadal climatology of the spring thermal bar 5 days and 15 days after the first appearance of $4^{\circ} \mathrm{C}$ in the 1990s and 2060s. The first appearance occurs in the western arm in both decades. After 5 days, spring thermal bar already appears in the southeast in the 2060s (Fig. 5b) but is absent in the 1990s (Fig. 5a). After 15 days, $4^{\circ} \mathrm{C}$ appears in Thunder Bay in both decades. By this time though, the thermal bar has propagated further offshore in the mid-century especially in the eastern basin compared to the 1990s (Fig. $5 \mathrm{c}, \mathrm{d})$. The entire surface water is much warmer in the 2060s after 15 days. The decadal climatology of the transition period decreases in the model from 54 days during the 1990s (5 May-28 June) to just 30 days (April 25-25 May) in the 2060s.

Another consequence of continual warming of Lake

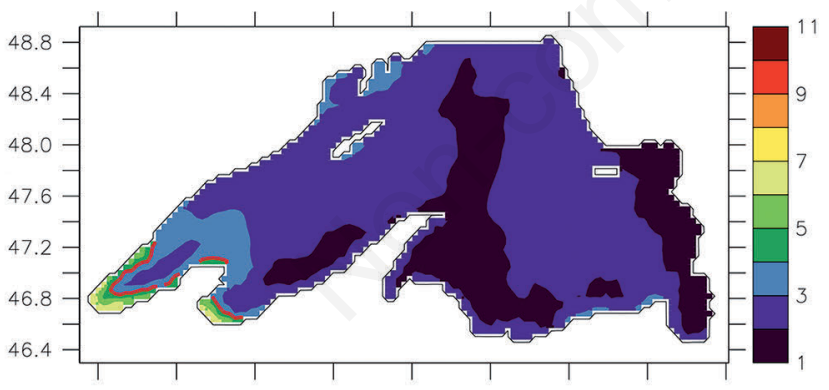

(c) 15 days after 4C appearance in spring 1990s

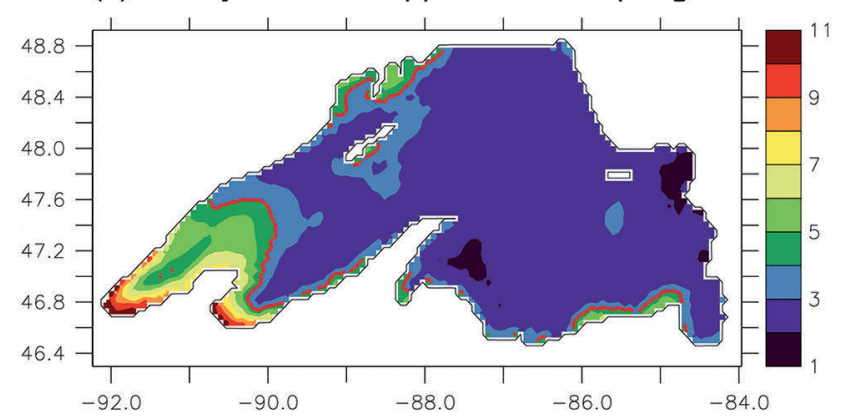

Superior is that the hypolimnion becomes increasingly isolated from the atmosphere. According to the tracer Age, Lake Superior's deep waters become progressively older through the mid-century (Fig. 6 b-d). Note that in the 1990s (Fig. 6, blue lines), Lake Superior is clearly dimictic below $100 \mathrm{~m}$, so that the hypolimnion is strongly ventilated during both the spring and fall overturning, when the hypolimnion Age is largely reset by vertical mixing that occurs preferentially over rough bottom topography (Matsumoto et al., 2015). Between the two overturning events, the hypolimnion ages because stratification prevents ventilation. Aging is stronger during the summer because stratification is longer and stronger than the winter. By the mid-century, the summertime aging of the hypolimnion increases even more. Peak average Age at water depth of 200-250 m increases from 145 days in the 1990s to 190 days by the 2040-2060 period (Fig. 6c). Not only does maximum Age increase by 45 days at those depths, but the timing of the maximum is delayed as well. In contrast, the winter hypolimnion aging is greatly stunted in the mid-century compared to the 1990s, indicating that the winter stratified period becomes much weaker. The trend towards stronger stratification and poorer ventilation over the summer season is evident at all depths (Fig. 6).

\section{(b) 5 days after $4 \mathrm{C}$ appearance in spring 2060s}

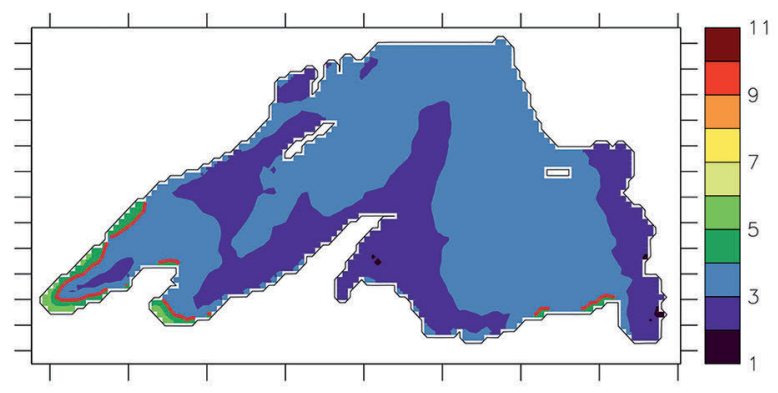

(d) 15 days after $4 \mathrm{C}$ appearance in spring $2060 \mathrm{~s}$

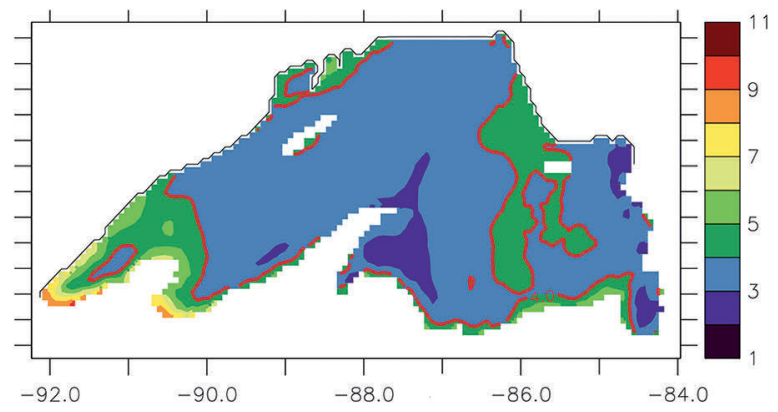

Fig. 5. Decadal climatology of the spring thermal bar position and LWST 5 days and 15 days after the first appearance of $4{ }^{\circ} \mathrm{C}$ in the 1990s and 2060s. The thermal bar is indicated by the thick red contour line. Background color is LWST (C). 


\section{Projection of Lake Superior primary production}

The lakewide annual primary production (PP) in the Lake Superior model is mostly within the range of 4.9-5.2 $\operatorname{Tg~C~yr}^{-1}$ ( $\mathrm{Tg} \mathrm{C}=10^{12}$ grams C) during the 1990s (Fig. 7a), consistent with data-based estimates (Cotner et al., 2004; Urban et al., 2005; Sterner, 2010). Annual PP increases in the model through the mid-century decades at the rate of approximately $0.1 \mathrm{Tg} \mathrm{C}$ decade $^{-1}$. In some years, annual PP reaches almost 6.0 $\mathrm{Tg} \mathrm{C} \mathrm{yr}^{-1}$. There is a clear phenological shift associated with this annual PP increase. Whereas the daily PP peaks around July 23 in the 1990s, it peaks approximately 25 days earlier in 2040s and 2050s and almost 2 weeks earlier in 2060s (Fig. 8).
The near ubiquitous DCM in Lake Superior (Barbiero and Tuchman, 2004) is faithfully reproduced in the model. DCM is identified in the model as a peak chlorophyll concentration below surface. The strength of the DCM is defined as the change in the chlorophyll concentration with depth between the depth of the DCM and surface. There is a clear trend in the lakewide DCM, both in strength (Fig. 7b) and depth (Fig. 7c). The lakewide DCM strength increases by nearly $40 \%$ from approximately $0.012 \mathrm{mg} \mathrm{Chl} \mathrm{m}^{-2}$ in the $1990 \mathrm{~s}$ to $0.017 \mathrm{mg} \mathrm{Chl} \mathrm{m}^{-2}$ near the end of the mid-century. The lakewide DCM depth increases from about $23 \mathrm{~m}$ water depth in the 1990s to about $27 \mathrm{~m}$ by 2070 .
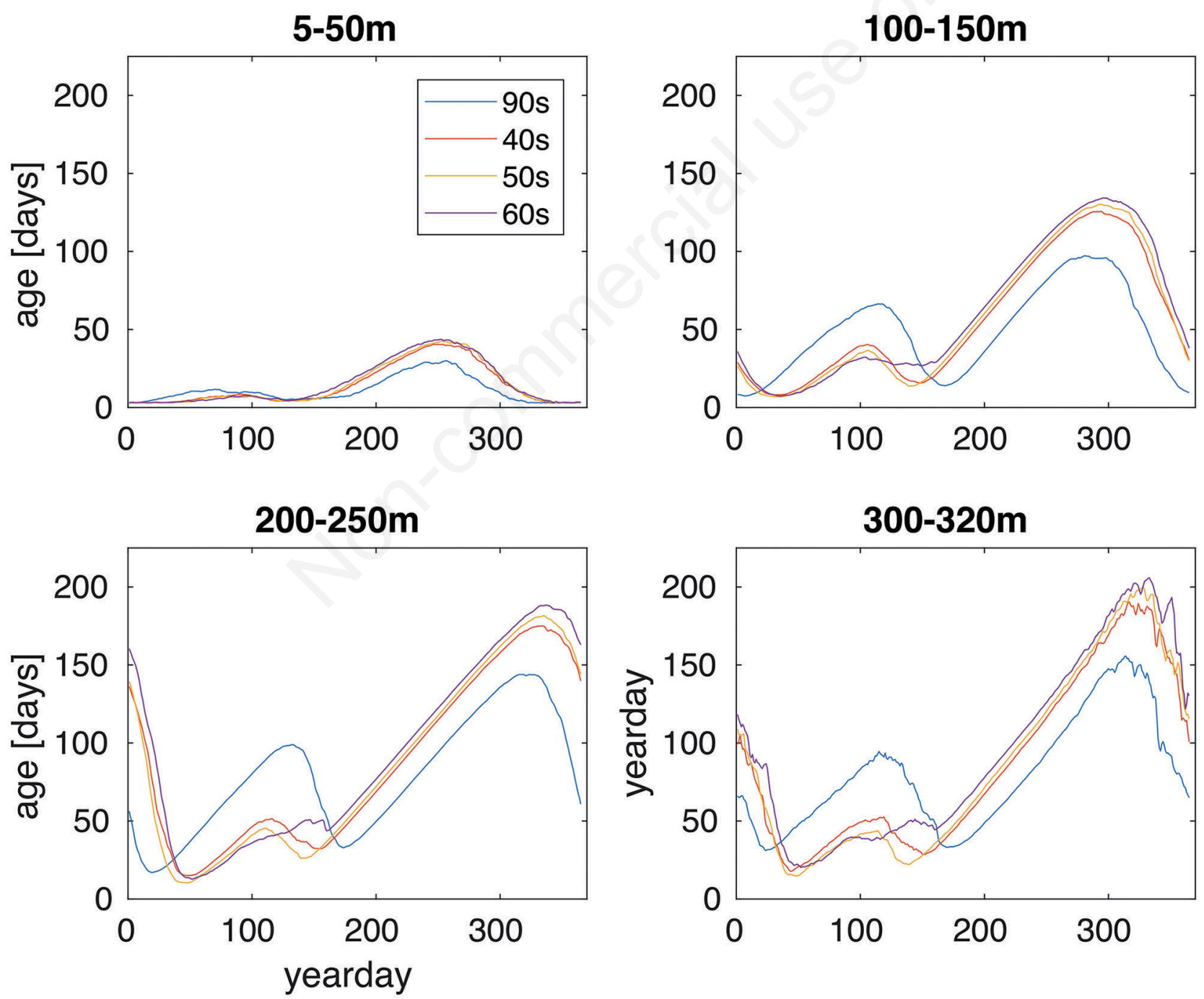

Fig. 6. Mean lakewide Age, averaged over four depth ranges for each decadal climatology. Spring and fall overturning is indicated by Age's minima. The decadal Ages are not reset completely to zero because overturning occurs at different times throughout the lake and from year to year. 


\section{DISCUSSION}

Physical changes projected by the Lake Superior model for the mid-century are internally consistent. As the regional climate forcing from CRCM-CCSM increases heat flux into Lake Superior, the lake warms in all seasons, making winters milder and summers hotter.

In the winter, ice cover becomes more variable from year to year but generally shrinks, especially in the open lake (Figs. 3c and 4f). This can have significant regional economic implications in terms of shipping in Lake Superior, for example, because Duluth is an international port. Commercial navigation is allowed on the lake dependent upon weather and lake ice. If the shipping schedule is opened for a longer period of time, or becomes year-round, it would force changes in ground transportation, employment, and all subsequent supplychain industries that connect to shipping. Reduced ice cover also would mean that waves in the winter will not be suppressed, thus increasing the risk of wave erosion of the coast and reducing habitability (Mackey, 2012) and increasing costs of infrastructure repair.

LWST in future winters does not become as cold as before, weakening the inverse temperature gradient. As a result, vertical mixing and ventilation largely continue during the winter, thereby preventing the deep lake waters from aging (Fig. 6).

In contrast, lateral mixing in the lake appears to not be much affected by future warming. Although the results are not shown here, we conducted another passive tracer experiment, where regional dyes were released in several embayments around the lake at the beginning of each model year (i.e., midwinter). Their horizontal distributions with time between the 1990s and mid-century did not change significantly. McKinney et al. (2018) found increased exchange between nearshore and offshore

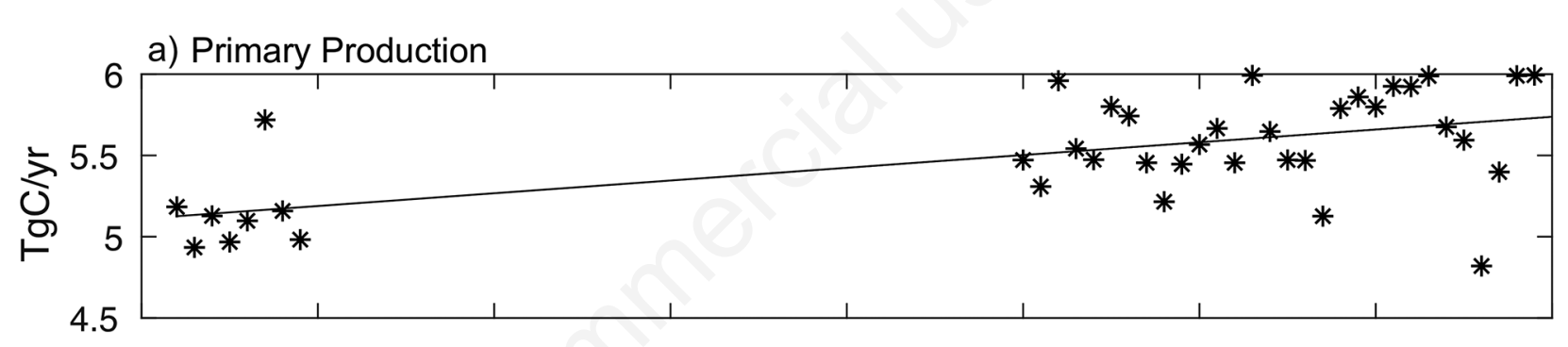

\section{b) DCM Strength}

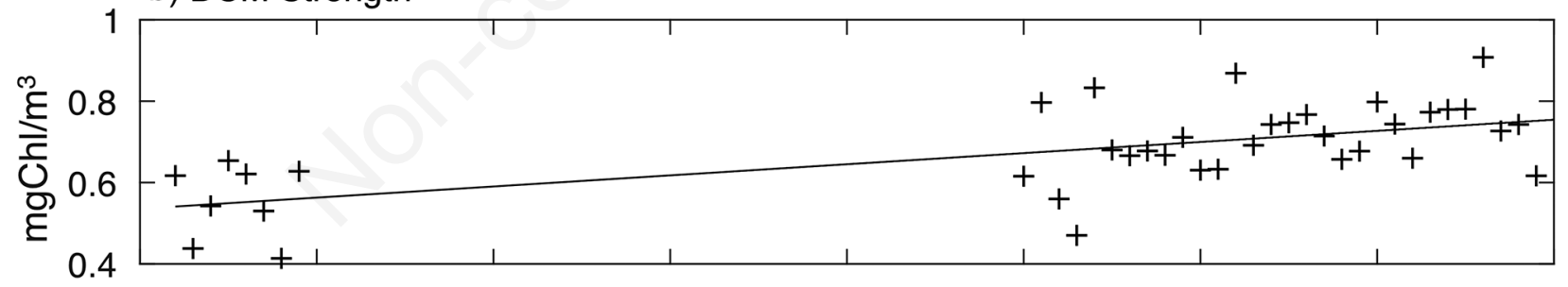

c) DCM Depth

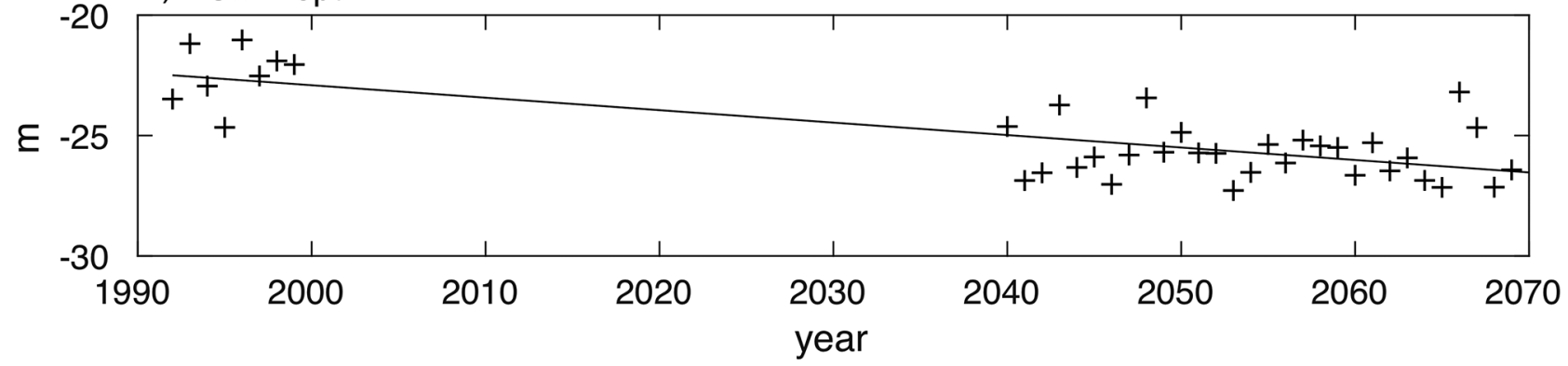

Fig. 7. Time series of modeled annual lakewide mean biological characteristics for the historical period 1992-1999 and a future projected scenario 2040-2069. a) Total gross primary production; b) deep chlorophyll maximum (DCM) strength, defined as $[\mathrm{Chl}]_{\mathrm{DCM}}-[\mathrm{Chl}]_{\mathrm{surface}}$; c) depth of the DCM. Trendlines are least-squares linear fit to the annual averaged and statistically significant. 
waters in the late winter/early spring was correlated to wind speed. The CRCM-CCSM wind speeds are not projected to change significantly into the next century, which may explain why we do not see much variability in the dye dispersal.

Summer in the mid-century becomes much stronger and longer. Consistent with lessons from available studies (Piccolroaz et al., 2015; Zhong et al., 2016, 2018; Ye et al., 2019), the model projects that as heat is concentrated in the ever-thinning MLD and the stratified period begins earlier in the year, LWST warming is enhanced (Figs. 3a and 4b). The magnitude of the projected annual lakewide mean LWST warming is $\sim 3^{\circ} \mathrm{C}$, comparable to both the SAT forcing of CRCM-CCSM and projected warming from the regional downscaling of Hayhoe et al. (2010). If summer alone is examined, the projected warming is even greater: lakewide LWST increases by $4^{\circ} \mathrm{C}$ from the 1990 s to the end of the 2060s. This is the same amount of warming predicted for the same period by Trumpickas et al. (2009), who apply a simple statistical relationship between LWST and SAT to a future SAT projection from a global model. The projected summertime warming over 6 decades translates to $0.66^{\circ} \mathrm{C}$ per decade, which is nearly twice the global mean rate of warming over the recent historical period, ensuring that Lake Superior remains a hotspot of warming lakes worldwide (O'Reilly et al., 2015).

There is debate as to what drives the enhanced, summertime warming in the Laurentian Great Lakes, but there are a number of elements in our model simulation that help drive the warming. One is a reduction in winter ice cover and duration (Mason et al., 2016), although the importance of winter ice in subsequent warming has been challenged (Zhong et al., 2016; Ye et al., 2019). Another driver is an earlier and faster onset of stratification (Austin and Colman, 2007; Piccolroaz et al., 2015; Zhong et al., 2016), which unsurprisingly is associated with reduced ice. Also, identified as an important driver is high summertime air temperature (Piccolroaz et al., 2015; Zhong et al., 2018), which was noted above in our forcing. The fact that Lake Superior is a cold lake to begin with (Zhong et al., 2018) may also explain the fast summertime warming in our projection.

As MLD thins and LWST rises during summer, the water column stratification becomes stronger. The lakewide strengthening of stratification leads to a decoupling of the epilimnion and hypolimnion. Consequently, the deep water Age increases at all depths and by 45 days at $225 \mathrm{~m}$ in the mid-century over the 1990s (Fig. 6). It signals that the deep lake waters become increasingly isolated from the atmosphere over the summer stratified period. There is thus a concern that hypolimnetic oxygen $\left(\mathrm{O}_{2}\right)$ might become depleted as enhanced stratification reduces the supply of dissolved $\mathrm{O}_{2}$ to the interior. In aquatic systems with moderate levels of biological production, interior $\mathrm{O}_{2}$ is expected to be related to ventilation age, which is a measure of cumulative

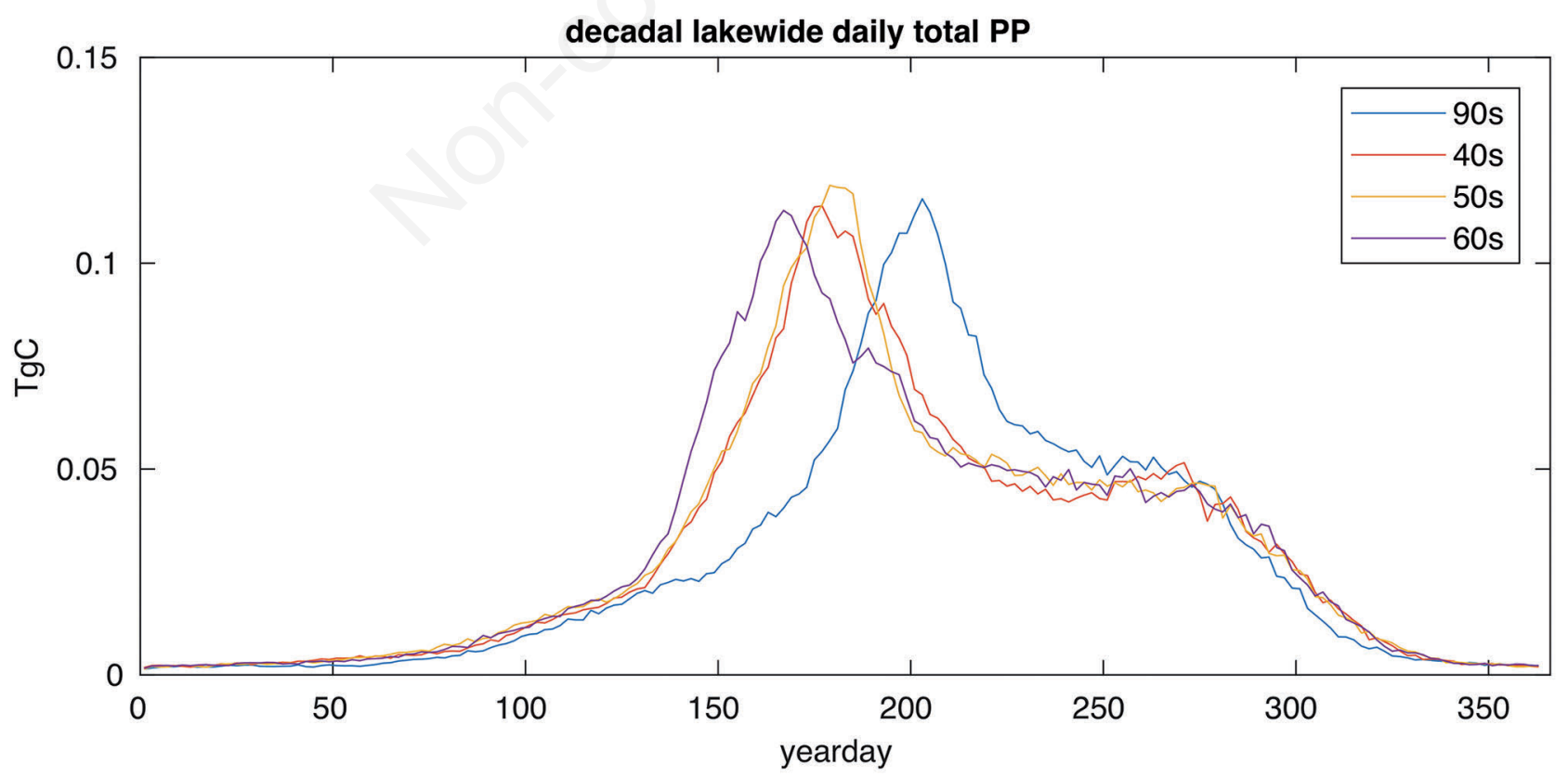

Fig. 8. Decadal climatology of model-simulated annual lakewide primary production. The areas under the curves indicate the integrated, annual primary production. 
respiration that consumes $\mathrm{O}_{2}$ in a parcel of water while being isolated from the atmosphere. This relationship is clearly seen in the world ocean, for example, between dissolved $\mathrm{O}_{2}$ and radiocarbon age. However, the relationship is absent in Lake Superior, where physics (i.e., vigorous transport of $\mathrm{O}_{2}$ ) dominates over biology (i.e., weak $\mathrm{O}_{2}$ consumption by respiration) (Matsumoto et $a l ., 2015)$. If Lake Superior remains vigorously mixed and oligotrophic, there is probably little concern that the increased aging of hypolimnion would lead to serious deoxygenation.

While the projected changes in LWST, ice, and summer stratification have potentially significant impacts for the stakeholders who live near Lake Superior, the changes in ventilation suggest that Lake Superior would become a fundamentally different kind of lake. Specifically, tracer Age (Fig. 6) indicates that the dimictic behavior, which so strongly characterizes today's Lake Superior and other mid-latitude lakes, may be eroding. In fact, tracer Age does not get reset in the spring in the 2060 s, which at face value means that overturning does not occur and thus the lake is no longer dimictic. A recent study based on remote sensing already suggests that two of the Laurentian Great Lakes did not overturn in a recent year (Fichot et al., 2017). The effects of the lake becoming monomictic can include differential changes in warming trend, ice cover, and nutrient distribution (Woolway and Merchant, 2018).

Our projection of Lake Superior's physical features (LWST, MLD, ice) are entirely consistent with the current trend of strengthening and lengthening the summer stratified season (McCormick and Fahnenstiel, 1999; Austin and Colman, 2007, 2008), and weakening and shortening the winter stratified and ice season (Assel, 2003, 2005; Howk, 2009). Projected warming of LWST, particularly strong in the eastern basin (Fig. 4b), is also consistent with more recent observations of faster warming in deeper waters (Mason et al., 2016; Zhong et al., 2016; Woolway and Merchant, 2018).

Earlier warming in the shallow waters, simulated on the southeast coast (Fig. 5b), has also been pointed out (Zhong et al., 2018). Given these consistencies, the projected trends thus appear quite reasonable, even while the specific magnitudes of changes simulated by our model for the future are simply projections. These trends can have important implications on shifting patterns of evaporation year round and lake effect snow in the winter. The trends also will expand the habitat of warm-water species in the summer, increasing the risk of warmerwater species invading Lake Superior. Zebra and quagga mussels, for example, are already present in the lakes ports (Grigorovich et al., 2008).

Projected changes to Lake Superior's biology are consistent with the physical changes. Annual PP in the mid-century increases compared to the 1990s (Fig. 7a), largely because the summer growing season is longer and LWST rises. It has been reported that temperature is the strongest driver of PP in Lake Superior today (Sterner, 2010). Because the growing season begins earlier, the lakewide daily PP peaks more than one month earlier near the end of the mid-century compared to the 1990s (Fig. 8). This phenological change could have a wide, cascading effect throughout Lake Superior's food chain as well as fisheries. If the efficiency of energy conversion between trophic levels remains the same, then an increase in PP could translate to larger fish biomass. The timing of activities associated with fisheries (e.g., fish harvest, storage, processing, and transport), may shift to an earlier time of the year. However, earlier warming may also trigger a mismatch in the timing of fish hatches and their ultimate food source, phytoplankton. This could lead to a shift in fish species and/or abundance. These alterations may force significant changes in the local and regional economies.

The DCM is projected to become stronger and deeper (Fig.7). At first, the deepening seems puzzling when we consider the projection that MLD shoals. These projections indicate that somehow MLD and DCM are decoupling. In our earlier work (White and Matsumoto, 2012), we identified photoadaptation as exerting a dominant control over the presence of DCM in Lake Superior. In our model, photoadaptation is activated under low light conditions and relatively greater nutrient availability according to the formulation of Geider (1996). The MLD-DCM decoupling could thus be explained by increased PP (Fig. 7a) causing both: i) lower light conditions through self-shading; and ii) surface nutrient depletion pushing the nutricline deeper. The first explanation however seems less likely in the oligotrophic Lake Superior, and the rapid attenuation of light with depth would shoal the base of the photic layer, which would be inconsistent with a deepening DCM. Given that DCM is a prominent biological feature of Lake Superior, its projected change in the coming decades can also be considered an indication of Lake Superior changing into a different kind of lake.

\section{CONCLUSIONS}

In this study, we employed a realistically configured, 3D physical-biogeochemical model of Lake Superior to project its physical and biological states into the midcentury (2040-2069) under a 'business as usual' warming scenario. The atmospheric boundary conditions that drive our lake model were obtained from a regional climate model, which closely tracks the ensemble mean of NARCCAP regional models. Our projections include significant reduction in both winter ice cover and winter 
water column stratification. Ventilation of interior waters will thus be enhanced over the winter season. For the summer, our model projects the season to begin earlier and last longer. Summertime stratification will be more enhanced, thus reducing ventilation. Our model predicts that summertime biological production would start and peak earlier and become larger overall as these physical changes occur. These physical and biological changes could shift the habitat in favor of warm water species as well as invasive species at all levels of the trophic pyramid. Potentially, these changes have important implications for stakeholders with interests in shipping, coastal habitability, fishing, water quality, and recreation. Perhaps more fundamentally, the projected changes imply that Lake Superior may change into a different kind of lake with a dramatically weakened dimictic behavior.

\section{REFERENCES}

Assel RA, 2003. An electronic atlas of Great Lakes ice cover. NOAA Great Lakes Ice Atlas. Great Lakes Environmental Research Laboratory, Ann Arbor:: 48105 pp.

Assel RA, 2005. Great Lakes ice cover climatology update: winters 2003, 2004, and 2005. NOAA Technical Memorandum GLERL-135.

Austin J, Colman S, 2008. A century of temperature variability in Lake Superior. Limnol. Oceanogr. 53:2724-2730.

Barbiero RP, Tuchman ML, 2004. The deep chlorophyll maximum in Lake Superior. J. Gt. Lakes Res. 30:256-268.

Beletsky D, Schwab DJ, 2001. Modeling circulation and thermal structure in Lake Michigan: Annual cycle and interannual variability. J. Geophys. Res.-Oceans 106:19745-19771.

Bennington V, McKinley G, Wu CH, 2010. General circulation of Lake Superior: Mean, variability, and trends from 1979 to 2006. J. Geophys. Res. 115. doi:10.1029/2010JC006261.

Butcher JB, Nover D, Johnson TE, Clark CM, 2015. Sensitivity of lake thermal and mixing dynamics to climate change. Clim. Change 129:295-305.

Caya D, Laprise R, 1999. A semi-implicit semi-Lagrangian regional climate model: The Canadian RCM. Mon. Weather Rev. 127:341-362.

Chen CS, Zhu JR, Ralph E, Green SA, Budd JW, Zhang FY, 2001. Prognostic modeling studies of the Keweenaw current in Lake Superior. Part I: Formation and evolution. J. Phys. Oceanogr. 31:379-395.

Collins W, Bitz CM, Blackmon ML, Bonan GB, Bretherton CS, Carton JA, Chang P, Doney S, Hack JJ, Henderson TB, Kiehl JT, Large W, et al., 2006. The Community Climate System Model version 3 (CCSM3). J. Clim. 19:2122-2143.

Cotner JB, Biddanda B, Makino W, Stets E, 2004. Organic carbon biogeochemistry of Lake Superior. Aquat. Ecosyst. Health Manag. 7:451-464.

Czernecki B, Ptak M, 2018. The impact of global warming on lake surface water temperature in Poland - the application of empirical-statistical downscaling, 1971-2100. J. Limnol. 77:31707. Doi: 10.4081/jlimnol.2018.1707.

Fang X, Stefan HG, 2009. Simulations of climate effects on water temperature, dissolved oxygen, and ice and snow covers in lakes of the contiguous United States under past and future climate scenarios. Limnol. Oceanogr. 54:2359-2370.

Fichot C, Matsumoto K, Holt B, Gierach M, Tokos K, 2017. Assessing change in the overturning behaviors of the Laurentian Great Lakes using remote sensing, presented at AGU Fall Meeting, Dec. 11-15, 2017, New Orleans.

Geider RJ, MacIntyre HL, Kana TM, 1996. A dynamic model of photadaptation in phytoplankton. Limnol. Oceanogr. 41:1-15.

Grigorovich IA, Kelly JR, Darling JA, West CW, 2008. The quagga mussel invades the Lake Superior basin. J. Gt. Lakes Res. 34:342-350.

Hayhoe K, VanDorn J, Croley T, Schlegal N, Wuebbles D, 2010. Regional climate change projections for Chicago and the US Great Lakes. J. Gt. Lakes Res. 36:7-21.

Howk F, 2009. Changes in Lake Superior ice cover at Bayfield, Wisconsin. J. Gt. Lakes Res. 35:159-162.

$\mathrm{Hu} \mathrm{H}$, Wang J, 2010. Modeling effects of tidal and wave mixing on circulation and thermohaline structures in the Bering Sea: Process studies. J. Geophys. Res.-Oceans 115:C01006.

Huang A, Rao YR, Lu Y, 2010. Evaluation of a 3-D hydrodynamic model and atmospheric forecast forcing using observations in Lake Ontario. J. Geophys. Res.-Oceans 115:C02004.

IPCC, 2013. Climate Change 2013: The Physical Science Basis. Contribution of Working Group I to the Fifth Assessment Report of the Intergovernmental Panel on Climate Change. Cambridge University Press, Cambridge and New York: $1535 \mathrm{pp}$.

Mackey SD, 2012. Great Lakes Nearshore and Coastal Systems In: U.S. National Climate Assessment Midwest Technical Input Report, Great Lakes Integrated Sciences and Assessments (GLISA) Center.

Mason LA, Riseng CM, Gronewold AD, Rutherford ES, Wang J, Clites A, Smith SDP, McIntyre PB, 2016. Fine-scale spatial variation in ice cover and surface temperature trends across the surface of the Laurentian Great Lakes. Clim. Change 138:71-83.

Matsumoto K, Tokos K, Gregory C, 2015. Ventilation and dissolved oxygen cycle in Lake Superior: Insights from a numerical model. Geochem. Geophys. Geosystems 16:doi:10.1002/2015GC005916.

McCormick MJ, Fahnenstiel GL, 1999. Recent climatic trends in nearshore water temperatures in the St. Lawrence Great Lakes. Limnol. Oceanogr. 44:530-540.

McKinney P, Holt B, Matsumoto K, 2012. Small eddies observed in Lake Superior using SAR and sea surface temperature data. J. Gt. Lakes Res. 38:786-797.

McKinney P, Tokos K, Matsumoto K, 2018. Modeling nearshore-offshore exchange in Lake Superior. Plos One 13:e0193183.

Mearns LO, Sain S, Leung LR, Bukovsky MS, McGinnis S, Biner S, Caya D, Arritt RW, Gutowski W, Takle E, Snyder M, Jones RG, et al., 2013. Climate change projections of the North American Regional Climate Change Assessment Program (NARCCAP). Clim. Change 120:965-975.

Melillo JM, Richmond T, Yohe GW, 2014. Climate Change Impacts of the United States: The Third National Assessment: 841 pp. 
Mellor GL, Yamada T, 1982. Development of a turbulence closure model for physical fluid problems. Rev. Geophys. 20:851-875.

Music B, Frigon A, Lofgren B, Turcotte R, Cyr JF, 2015. Present and future Laurentian Great Lakes hydroclimatic conditions as simulated by regional climate models with an emphasis on Lake Michigan-Huron. Clim. Change 130:603-618.

Nakicenovic N, Davidson O, Davis G, Grubler A, Kram T, Rovere ELL, Metz B, Morita T, Pepper W, Pitcher H, Sankovski A, Shukla P, et al., 2000. Emissions scenarios - summary for policymakers. A special report of working group III of the Intergovernmental Panel on Climate Change.

O'Reilly CM, Sharma S, Gray DK, Hampton SE, Read JS, Rowley RJ, Schneider P, Lenters JD, McIntyre PB, Kraemer BM, Weyhenmeyer GA, Straile D, et al., 2015. Rapid and highly variable warming of lake surface waters around the globe. Geophys. Res. Lett. 42:10773-10781.

Piccolroaz S, Healey NC, Lenters JD, Schladow SG, Hook SJ, Sahoo GB, Toffolon M, 2018. On the predictability of lake surface temperature using air temperature in a changing climate: A case study for Lake Tahoe (U.S.A.). Limnol. Oceanogr. 63:243-261.

Piccolroaz S, Toffolon M, Majone B, 2015. The role of stratification on lakes' thermal response: The case of Lake Superior. Water Resour. Res. 51:7878-7894.

Pryor SC, Scavia D, Downer C, Gaden M, Iverson LI, Nordstrom R, Patz J, Robertson GP, 2014. Midwest, p. 418440 In: J.M. Melillo, T. Richmond and G.W. Yohe (eds.), Climate change impacts in the United States: The Third National Climate Assessment. U.S. Global Change Research Program, Washington DC.

Riahi K, Vuuren DP van, Kriegler E, Edmonds J, O’Neill BC, Fujimori S, Bauer N, Calvin K, Dellink R, Fricko O, Lutz W, Popp A, et al., 2017. The shared socioeconomic pathways and their energy, land use, and greenhouse gas emissions implications: An overview. Glob. Environ. Change 42:153-168.

Roberts JJ, Fausch KD, Schmidt TS, Walters DM, 2017. Thermal regimes of Rocky Mountain lakes warm with climate change. Plos One 12:e0179498.

Root TL, Prince JT, Hall KR, Schneider SH, Rosenzweig CE, Pounds JA, 2003. Fingerprints of global warming on wild animals and plants. Nature 421:57-60.

Schmid M, Hunziker S, Wüest A, 2014. Lake surface temperatures in a changing climate: A global sensitivity analysis. Clim. Change 124:301-315.

Schwab DJ, Bedford KW, 1999. The great lakes forecasting system, p. 157-173 In: C.N.K. Mooers (ed.), Coastal Ocean Prediction. American Geophysical Union, Washington DC.

Shchepetkin AF, McWilliams JC, 2005. The regional ocean modeling system (ROMS): A split-explicit, free surface, topography-following coordinate ocean model. Ocean Model. 9:347-404.

Shuter BJ, Minns CK, Fung SR, 2013. Empirical models for forecasting changes in the phenology of ice cover for Canadian lakes. Can. J. Fish. Aquat. Sci. 70:982-991.

Sterner R, 2010. In situ-measured primary production in Lake Superior. J. Gt. Lakes Res. 36:139-149.

Sugiyama N, Kravtsov S, Roebber P, 2018. Multiple climate regimes in an idealized lake-ice-atmosphere model. Clim. Dyn. 50:655-676.

Titze D, Austin J, 2014. Winter thermal structure of Lake Superior. Limnol. Oceanogr. 59:1336-1348.

Titze D, Austin J, 2016. Novel, direct observations of ice on Lake Superior during the high ice coverage of winter 20132014. J. Gt. Lakes Res. 42:997-1006.

Trumpickas J, Shuter BJ, Minns CK, 2009. Forecasting impacts of climate change on Great Lakes surface water temperatures. J. Gt. Lakes Res. 35:454-463.

Urban NR, Auer MT, Green SA, Lu X, Apul DS, Powell KD, Bub L, 2005. Carbon cycling in Lake Superior. J. Geophys. Res.-Oceans 110:C06S90. doi:10.1029/2003JC002230.

Van Cleave K, Lenters JD, Wang J, Verhamme EM, 2014. A regime shift in Lake Superior ice cover, evaporation, and water temperature following the warm El Niño winter of 1997-1998. Limnol. Oceanogr. 59:1889-1898.

Weinberger S, Vetter M, 2014. Lake heat content and stability variation due to climate change: Coupled regional climate model (REMO)-lake model (DYRESM) analysis. J. Limnol. 73:93-105.

White B, Austin J, Matsumoto K, 2012. A three dimensional model of Lake Superior with ice and biogeochemistry. J. Gt. Lakes Res. 38:61-71.

White B, Matsumoto K, 2012. Causal mechanisms of the deep chlorophyll maximum in Lake Superior: A numerical modeling investigation. J. Gt. Lakes Res. 38:504-513.

Woolway RI, Merchant CJ, 2018. Intralake heterogeneity of thermal responses to climate change: A study of large northern hemisphere lakes. J. Geophys. Res.-Atmos 123:3087-3098.

Xue P, Pal JS, Ye X, Lenters JD, Huang C, Chu PY, 2017. Improving the simulation of large lakes in regional climate modeling: Two-way lake-atmosphere coupling with a 3D hydrodynamic model of the great lakes. J. Clim. 30:16051627.

Xue P, Schwab DJ, Hu S, 2015. An investigation of the thermal response tometeorological forcing in a hydrodynamic model of Lake Superior. J. Geophys. Res. Oceans 120:5233-5253.

Ye X, Anderson EJ, Chu PY, Huang C, Xue P, 2019. Impact of water mixing and ice formation on the warming of Lake Superior: A model-guided mechanism study. Limnol. Oceanogr. 64:558-574.

Zhong Y, Notaro M, Vavrus SJ, 2018. Spatially variable warming of the Laurentian Great Lakes: an interaction of bathymetry and climate. Clim. Dyn. 52:5833-5848.

Zhong Y, Notaro M, Vavrus SJ, Foster MJ, 2016. Recent accelerated warming of the Laurentian Great Lakes: Physical drivers. Limnol. Oceanogr. 61:1762-1786. 